\title{
THE UNFAIR COMMERCIAL PRACTICES DIRECTIVE IN THE UK
}

\author{
Marios Koutsias ${ }^{*}$ and Chris Willett**
}

\begin{abstract}
This article shows that the UK has blended preventive and traditional UK criminal enforcement techniques to implement the UCPD; these techniques have been 'Europeanised' by the UCPD unfairness concepts; and the UCPD may also cause UK private law to be Europeanised in more 'spontaneous' ways. However, there are limits to this Europeanising effect. First of all, the 'home grown' financial services regime is likely to remain dominant, inter alia, because of the high standards of protection it sets and because of Article 3(9) of the UCPD, which exempts financial services from the full harmonisation principle. Secondly, judges may limit the extent of Europeanisation. The UCPD's European concepts of fairness often have the potential to increase standards of protection relative to pre-existing UK law. However, these concepts are sufficiently open textured as to run the risk of being interpreted in non-protective ways, based on underlying UK judicial ethics of self-interest and self-reliance. So far, High Court judges have taken quite a protective approach to interpretation of the UCPD concepts. However, the full impact of the UCPD European fairness standards in the UK will only become clear when cases reach the appeal courts; and the ECJ more fully develops its approach.
\end{abstract}

Keywords: Europeanisation; preventive, criminal and private law; ECJ.

\section{Introduction}

This article considers the manner in which the Unfair Commercial Practices Directive ${ }^{1}$ (UCPD) has been received in the UK. It shows that the UK has used a blend of preventive and traditional UK criminal enforcement techniques, while we argue that these techniques have been 'Europeanised' by the open-textured nature and breadth of application of the UCPD unfairness concepts. In addition, although the UCPD does not require member states to grant private law enforcement rights, we also argue that UK private law may nevertheless be Europeanised by the UCPD in more 'spontaneous' (less direct) ways, as a result of the planned introduction of private law remedies for at least certain violations of the (distinctly European) UCPD concepts of fairness.

Nevertheless, our further contention is that there are limits to this Europeanising effect. First of all, in the important area of financial services, for example, the 'home grown' regime is likely to remain dominant, because it operates within a well-established institutional structure and may well set higher standards of protection than those in the UCPD. (This is permitted by Article 3 (9) of the UCPD, which exempts financial services and immovable property from the full harmonisation principle that applies generally under the UCPD.)

Secondly, there is a possibility that judges may limit the extent of Europeanisation. In contrast to the particular position in relation to financial services, the UCPD's European concepts of fairness often have the potential to increase standards of protection relative to pre-existing UK law. However, these European concepts are sufficiently open textured as to run the risk of being interpreted in non-protective ways, based on underlying UK judicial ethics of self-interest and self-reliance. So far, High Court judges have taken a relatively protective approach to interpretation of the UCPD concepts. However, we

\footnotetext{
* $\quad$ Lecturer in Law, University of Essex.

** Professor of Commercial Law, University of Essex.

2005/29/EC; G. Howells, H. Micklitz, \& T. Wilhelmsson, European Fair Trading Law (2006); S. Weatherill and U. Bernitz, The Regulation of Unfair Commercial Practices under EC Directive 2005/29 (2007); C. Willett, 'Fairness and Consumer Decision Making under the Unfair Commercial Practices Directive' (2010), 33 JCP 247.
} 
will only really have a clear picture as to the impact of European fairness standards in the UK when we hear the views of the appeal courts; and hear more from the ECJ.

\section{UK Implementation: Techniques and Europeanisation}

\subsection{UCPD Unfairness Concepts and Requirements}

As is well known, the UCPD contains general clauses on 'misleading practices' (divided into 'misleading actions' and 'misleading omissions') and 'aggressive practices' (the main operative provisions in practice), as well as an overriding general clause, catching practices that are 'contrary to the requirements of professional diligence'. ${ }^{2}$ It seems that this 'professional diligence' clause is intended to encapsulate, but possibly sometimes extend beyond, what would be caught by the general clauses on misleading practices and on aggressive practices. ${ }^{3}$ There is also a list of 31 practices that are in all circumstances considered to be unfair, i.e. without application of the above general clauses on misleading and aggressive practices. ${ }^{4}$

The UCPD requires member states to ensure that there are adequate and effective means to combat the use of practices that are unfair in one of the above ways, including means by which persons or organisations regarded under national law as having a legitimate interest in combating unfair commercial practices may take legal or administrative action against such practices. ${ }^{5}$

\subsection{Preventive Control}

The UCPD was implemented by the Consumer Protection from Unfair Trading Regulations (CPUTR) 2008. ${ }^{6}$ These introduce an injunctive or 'cease and desist' form of preventive control known as an 'enforcement order'. They provide that where a practice is unfair (following the definitions in the UCPD itself), it amounts to a 'Community infringement' under the Enterprise Act (EA) 2002, thereby allowing enforcement authorities to ask a court to issue an 'enforcement order' against the continued use of the practice.

Enforcement orders can be obtained (in the High Court or county court in England, Wales or Northern Ireland or the Court of Session or Sheriff Court in Scotland) against a trader carrying out the practice or likely to carry out the practice. ${ }^{7}$ Under EA, s. 213, enforcement orders can be sought by the Office of Fair Trading (OFT), local trading standards authorities and the Department of Enterprise, Trade and Investment in Northern Ireland (all deemed 'general enforcers'). They can also be sought by those

\footnotetext{
Arts. 5-9.

3 See Micklitz, in G. Howells, H. Micklitz, \& T. Wilhelmsson (eds.), European Fair Trading Law (2006), at 121 .

UCPD, Ann. 1.

UCPD Art. 11

2008/SI/1277. For the full background to implementation of the Directive see <www.berr.gov.uk/ consultations/page39674.html>. See also C. Twigg-Flesner and D. Parry, 'The Challenges Posed by the Implementation of the Directive into Domestic Law - a UK Perspective', in S. Weatherill and U. Bernitz (eds.), The Regulation of Unfair Commercial Practices under EC Directive 2005/29 (2007); G. Howells, 'The End of an Era - Implementing the Unfair Commercial Practices Directive in the United Kingdom: Punctual Criminal Law Gives Way to a General Criminal/Civil Law Standard', 11 Journal of Business Law 183 (2009); H. Collins, 'Harmonisation by Example: European Laws against Unfair Commercial Practices', 73 Modern Law Review 89 (2010); C. Willett, 'Unfairness under the Consumer Protection from Unfair Trading Regulations', in J. Devenney, L. Fox O’Mahony, and M. Kenny (eds.), Unconscionability in European Private Financial Transactions (2010) 350; J. Williams and C. Hare, 'Early Experiences of the Enforcement of the Unfair Commercial Practices Directive in Scotland', 33 Journal of Consumer Policy 377 (2010); P. Cartwright, 'Under Pressure: Regulating Aggressive Practices in the UK', 2011 Lloyds Maritime and Commercial Law Quarterly 123; and C. Willett and M. Morgan-Taylor, 'Consumer Protection', in J. Chuah and M. Furmston (eds.), Commercial and Consumer Law (forthcoming 2012) 7.8.

EA, s. 212 and 217 and CPUTR, Reg. 26; and Willett and Morgan-Taylor, above n. 6.
} 
designated as enforcers by the Secretary of State (thus far the Civil Aviation Authority, the Information Commissioner, the Rail Regulator, the Gas and Electricity Markets Authority and the Director Generals of Telecommunications, Water, Gas and Electricity for Northern Ireland). ${ }^{8}$ Enforcement orders can also be sought by those 'Community enforcers' listed in the Official Journal under Art. 4.3 of the Injunctions Directive (bodies from other Member States). (This is intended to facilitate cross-border cooperation in enforcement.) Finally, they can be sought by Consumer Protection Cooperation Enforcers, such as the Civil Aviation Authority, the Financial Services Authority, Ofcom, ICSTIS and the general enforcers mentioned above. ${ }^{10}$

Enforcement is coordinated by the OFT. The enforcer must consult the trader and the OFT to seek to ensure cessation of the practice. ${ }^{11}$ Normally, this consultation period is 14 days, but 7 days is sufficient for an interim order, and if the OFT considers it necessary, consultation can be dispensed with altogether. An enforcer may accept an 'undertaking' that the practice will cease (and, therefore, not proceed to seek an enforcement order). ${ }^{12}$

The OFT issued guidance on the new concepts of unfairness when the law was first passed. ${ }^{13}$ Of course, it must be emphasised that this guidance represents the OFT view as to how the concepts of unfairness should be understood - it being open to the courts (when cases come before them) to take a different view.

This 'enforcement order' regime for UCPD-based unfair practices fits within a broader regime of preventive control in UK consumer protection. Enforcement orders can also be obtained against other 'Community infringements', that is, actions that represent breaches of standards contained in various other EU directives. ${ }^{14}$ This would cover, for example, failure to abide by the various information obligations and cancellation rights that are provided for in directives on package travel, consumer credit, doorstep selling and distance selling. ${ }^{15}$ It also covers selling goods that do not meet the conformity standards in the Consumer Sales Directive (or failing to provide the remedies in the Consumer Sales Directive) ${ }^{16}$ the use of terms that are unfair under the Unfair Contract Terms Directive $;{ }^{17}$ and breaches of the provisions of the Timeshare, Electronic Commerce and Television Broadcasting Directives. ${ }^{18}$

Enforcement orders can also be obtained against so-called 'domestic infringements'. Essentially, 'domestic infringement' covers a variety of actions that represent breaches of contract, statutory duties, criminal offences and torts that harm 'the collective interests of consumers'. ${ }^{19}$ The label 'domestic' infringement is used to indicate that the actions in question represent breaches of standards that have been set by domestic law; that is, they have not come from EU law. So it would cover, for example, practices that amount to the criminal offence of harassment of debtors under the Administration of Justice Act (AJA), Section 40; and breaking contracts by not delivering promised goods or services. ${ }^{20}$ So quite apart from harassment representing a criminal offence and failure to deliver goods or services giving consumers the right to seek private law remedies for breach of contract, an enforcement order can be issued requiring such conduct to cease in future.

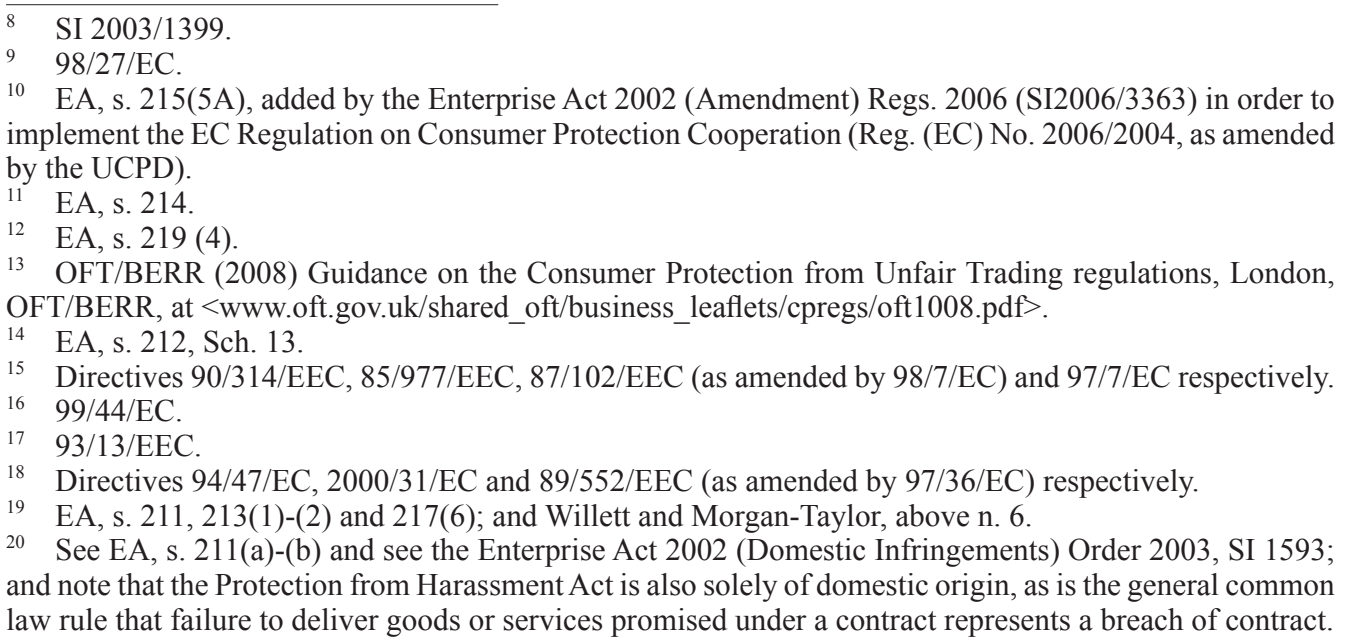




\subsection{Europeanisation of Preventive Enforcement through the 'General Clause'}

So we can see that tools for preventive control of unfairness as defined by the UCPD have been 'slotted in' to a pre-existing national regime of preventive consumer protection. However, it is our contention that this is more than a mere technical extension of such preventive consumer protection powers. The pre-existing 'domestic' and 'Community' infringements all tend to involve relatively narrow and specific issues (often only in particular sectors): for example, failure to provide specific types of information in doorstep and distance sales; supply of defective goods; use of unfair contract terms; harassment of debtors etc.

In contrast, the UCPD concepts of unfairness, which can now form the basis of preventive action, are much broader in their scope. The various 'general clauses' 'misleading actions', 'misleading omissions', 'aggressive practices', violation of 'professional diligence' - are 'general' partly because they are themselves very open textured. ${ }^{21}$ In addition, they can be called 'general' because they cover such vast ground. They cover practices ${ }^{22}$ 'before, during or after' any 'commercial transaction' ${ }^{23}$ (there being no restriction to particular types of transaction or sector). So in relation to almost all conceivable goods or services, there is a 'cradle to grave' regime covering practices such as advertising, persuasion and negotiation at the pre-contractual stage; post-contractual alterations or variations; performance, delivery etc by the trader; performance, payment etc by the consumer; complaint handling; after sales service; and enforcement by either party.

In short, UCPD implementation has brought a very significant expansion of the use of the 'general clause', a very significant 'Europeanisation' of the UK preventive consumer protection regime. ${ }^{24}$ (It is worth emphasising that use of an open-textured general clause that covers considerable ground is not only 'European' in the sense that it comes from a European Union directive, but also 'European' - and here, 'continental' European is the more precise term - in that this tradition of open-textured, broadly applicable general clauses is a tradition that is deeply embedded in the civil law legal tradition of continental Europe - and not the common law UK tradition. $)^{25}$

\subsection{Criminal Sanctions: Tradition, Rationales, Policies and Operation}

Criminal sanctions have been a core part of public enforcement of consumer law in the UK for centuries. There is plenty of scope for debate as to the rationales for using the criminal law in the consumer protection sphere ${ }^{26}$ Certainly, criminal sanctions can be viewed as having important deterrent effects that might be missing in the case of the

\footnotetext{
${ }^{21}$ See, on this, C. Willett, 'General Clauses and the Competing Ethics of European Consumer Law in the UK', 71 Cambridge Law Journal 412 (2012); and Willett, above n. 1.

22 Any 'Act, Omission, Course of Conduct or Representation' (UCPD Art. 2 (d)/CPUTR, Reg. 2 (1)).

23 UCPD, Art. 3 (1)/ CPUTR, Reg. 2 (1).

24 On Europeanisation see C. Twigg-Flesner, The Europeanisation of Contract Law (2008); C. TwiggFlesner (ed.), The Cambridge Companion to European Union Private Law (2010); R. Brownsword, H.W. Micklitz, L. Niglia, \& S. Weatherill, The Foundations of European Private Law (2011); and Willett, above n. 21. Of course, 'Europeanisation' more generally covers more than the use of concepts such as general clauses that derive from continental, civil law traditions than the common law tradition. It also covers, e.g., the way in these and other concepts are interpreted in an 'autonomous' European manner by the European Court of Justice; the 'spillover' or 'spontaneous' Europeanisation that may take place in areas not directly covered by a Directive (e.g. in private law, on which see below); and, indeed, the impact of barrier to trade rules on national contract and trade law (see C. Twigg-Flesner, The Europeanisation of Contract Law).

${ }_{25}$ Generally see G. Howells, 'General Clauses in European Consumer Law', in Micklitz (ed.), Verbraucherrecht in Deutschland (2005); and S. Grundman and D. Mazeaud, General Clauses and Standards in European Contract Law (2005).

${ }_{26}$ For an excellent and exhaustive review of rationales, see P. Cartwright, Consumer Protection and the Criminal Law (2001).
} 
preventive sanctions discussed above. More generally, the OFT has said that criminal enforcement should be used where

civil enforcement is unlikely to be effective in achieving a change in behavior and/or the breach is sufficiently serious that the conviction and punishment of offenders ought to be pursued, for example to protect the public and to provide wider deterrence. ${ }^{27}$

The OFT elaborates on this by saying that it is likely to consider beginning a criminal investigation:

- where traders deliberately or recklessly use deceptive, misleading or fraudulent practices;

- where traders deliberately or recklessly use aggressive, intimidating or coercive practices;

- where flagrant and/or persistent offending by a trader or group of associated traders has occurred or is occurring;

- where a particular unlawful practice is widespread, or there is a risk determined that criminal enforcement is likely to be the most effective means by which to set a precedent for future action; or

- where false statements are made or false documents provided in the course of dealings with the OFT or another enforcement body or where the investigation is otherwise obstructed. ${ }^{28}$

Criminal sanctions have been, and continue to be, used, for instance, in relation to food labelling, quality and safety; ${ }^{29}$ and general product safety. ${ }^{30}$ They were used against 'false trade descriptions' (Trade Descriptions Act-TDA-1968) (covering basically misleading statements about goods and services) and 'misleading pricing' (Consumer Protection Act 1987 Part III) until the implementation of the UCPD. These provisions were repealed by the CPUTR ${ }^{31}$ and replaced by offences based on the UCPD concepts. So a trader now commits an offence if he carries out a misleading act or omission or an aggressive practice (the definitions reflecting those in the UCPD) ${ }^{32}$ These are all strict liability offences, there being no mens rea requirement (i.e. no need to prove that the trader acted intentionally, recklessly or negligently). A trader also commits an offence if he contravenes the requirement of professional diligence. ${ }^{33}$ However, for the trader to be criminally liable for violation of the professional diligence standard, there is a mens rea requirement. The trader is guilty of an offence only if he 'knowingly or recklessly [engages] in conduct' that is contrary to professional diligence and materially distorts, or is likely to materially distort, consumer behaviour'. ${ }^{34}$ It is important to stress here that the trader need only be 'knowing or reckless' as to his own behaviour. There is no need for him to know of (or be reckless as to) its actual or likely effects on consumers.

Finally, a trader also commits an offence if he engages in any practice set out in paras. 1-10, 12-27 and 29-31 of the Schedule of practices that are always regarded as unfair. ${ }^{35}$

In the case of the misleading action and omission offences, the aggressive practice offence and the practices in Sch. 1, there are defences available. ${ }^{36}$ The defences are those that have long been used for 'consumer protection' offences in the UK so that earlier case law under the TDA and other legislation may still prove helpful.

27 OFT, Criminal Enforcement of the Consumer Protection from Unfair Trading Regulations (2010), para 2.1, available at $<$ www.oft.gov.uk/shared_oft/policy/OFT1273.pdf $>$.

Id, at 2.2

B. Atwood, K. Thompson, \& C. Willett, Food Law (2009).

Howells, above n. 6.

CPUTR, Schedule 4.

Regs. 9-11; and see Regs. 13 and 14 on penalties and time limits respectively.

Reg. 8.

Reg. 8(1) (a).

Reg. 12.

The defences are not available in the case of the 'violation of professional diligence' offence: if the 
One set of defences are those available under s. 17. Here the defendant must first prove that the commission of the offence is due to

- a mistake that must be a mistake by the person charged, rather than one of their employees; ${ }^{37}$ or

- reliance on information supplied to him by another person (whom the defendant must identify to the prosecution) ${ }^{38}$ for example, information as to mileage from previous owners of a vehicle ${ }^{39}$ or information on a product label placed there by the producer (and relied on by the retailer); ${ }^{40}$ or

- the act or default of another person (whom the defendant must identify to the prosecution $)^{41}$ who can be a party such as a sub-contractor or other party that is responsible for the activity in question, but can even be an employee, ${ }^{42}$ for example, as in Tesco v. Nattrass, ${ }^{43}$ where a supermarket manager who wrongly labelled washing powder counted as 'another person' for the purposes of the supermarket's defence; or

- an accident or another cause beyond his control, which may cover computer errors. $^{44}$

Having established one of the above criteria, the defendant must then establish that he took all reasonable precautions and exercised all due diligence to avoid the commission of the offence by himself or any person under his control. Whether there have been 'reasonable precautions' is a question of fact, which will be affected by the circumstances of each particular case. Different precautions may be necessary according to whether the defendant is a manufacturer, a retailer or a supplier of services, and what is required may well also vary according to whether the defendant is a large enterprise or a small corner shop. ${ }^{45}$ In general, the key is that an appropriate system must be in place to prevent the practice taking place, for example, devising an adequate training programme for employees ${ }^{46}$ testing products (e.g. to see if they comply with information on labels) ${ }^{47}$ or (in the case of false mileage readings on cars) checking the history, for example, through the registration document and obtaining statements from previous owners. ${ }^{48}$

Whether there has been 'due diligence' turns on whether the system of reasonable precautions has actually been used in practice. If it has not, then there will be no due diligence and the defence will fail. ${ }^{49}$

A further defence is provided by Reg. 18. There is a defence if the defendant can establish that it is his business to publish (or arrange for publication of) advertisements; he

trader has been 'knowing or reckless' (the required mens rea for this offence), then it is hard to see how he can have exercised 'reasonable precautions/due diligence' (s. 17 defence) or 'innocently' published an advertisement (s. 18 defence), so it would be illogical for the defences to be available.

37 Birkenhead Co-operative Society v. Roberts [1970] 1 WLR 1497.

38 Reg. 17(2).

39 See Simmons v. Potter, [1975] RTR 347 (although the due diligence element was not established in this case - see below); and Ealing LBC v. Taylor, [1995] CLR 156 (where due diligence was established - see below).

${ }^{40}$ Hurley v. Martinez, [1991] CCLR 1.

${ }^{41}$ Reg. 17(2).

42 So long as they are not so senior as to be an 'alter ego' of the company (e.g. members of the Board of Directors, managing director and other senior officers) (see Tesco v. Nattrass, [1971] 2 All ER 127).

43 Id.

44 See Berkshire CC v. Olympic Holidays Ltd, [1994] 13 Trading LR 251.

45 See Garrett v. Boots the Chemist, [1980].

46 See Tesco v. Nattrass, above n. 42.

47 Amos v. Melcom (Frozen Foods), [1985] 149 JP 712, DC (insufficient evidence of sampling to check if meat labelled 'rump steak' was actually thus).

48 See Richmond upon Thames LBC v. Motor Sales (Hounslow) Ltd, [1971] RTR 116; Wandsworth LBC v. Bentley, [1980] RTR 429 DC; and Ealing LBC v. Taylor, [1995] Crim LR 156. Even with some such checks, it has also been held that not enough had been done and that a statement disclaiming knowledge as to whether the mileage was correct was required as a 'reasonable precaution' against customers being misled (Simmons v. Potter [1975], RTR 347).

${ }_{49}$ See Turtington v. United Co-operative Ltd, [1993] Crim LR 376; and see the judgment of Lord Diplock in the Tesco v. Nattrass case, above n. 42 for guidance on due diligence. 
received the advertisement for publication in the ordinary course of business, and he did not know, and had no reason to suspect, that its publication would amount to an offence. This covers those (such as newspapers and magazines) who publish advertisements, as well as those (such as advertising agencies) who arrange for publication.

These defences are available partly because the offences are strict liability, and it is thought that some form of escape route from strict criminal liability should be available where blame is minimal. The 'reasonable precautions and due diligence' requirement can also be viewed as a way of incentivising traders to manage their affairs so as to avoid the behaviour in question. We would suggest that this is why, as we saw above, it is key to successful use of this defence to establish that an effective system was in place to prevent the practice taking place and that this system was operating properly in the circumstances in question.

\subsection{Europeanisation of Criminal Enforcement Through the 'General Clause'}

So we can see that the UK has chosen to back up preventive control of (UCPD defined) unfair practices with traditional UK criminal sanctions. However, again, although the UK may be using traditional, 'home-grown' enforcement tools to enforce the European standards of fairness, we would suggest that these standards of fairness are, themselves, Europeanising the home-grown enforcement tools. The point, again, is the general clause and the very broad application of fairness that it has introduced to UK criminal law.

To take one example, the pre-existing criminal rules tended not to cover statements made during the performance or enforcement of a contract. The TDA, for instance, was focused on statements about the goods or services themselves, tending to mean that the focus was on statements made at or around when the contract is first made. ${ }^{50}$ However, statements made in the context of performance or enforcement are covered by the new (Europeanised) regime. We noted above that the UCPD concept applies to practices 'before, during or after' any 'commercial transaction'. ${ }^{51}$ So the reach of criminal consumer protection law has been significantly extended by this European general clause. It will cover, for example, statements as to the rights of consumers, which might influence their decisions as to whether 'to exercise a contractual right' ${ }^{52}$ (possibly covering statements that deceive consumers as to their rights and that are therefore likely to cause them to make the decision not to enforce these rights).

\section{Spontaneous Europeanisation of Private Law}

The consumer contract laws of England and Scotland have certainly been significantly Europeanised over the past two or three decades. ${ }^{53}$ Most notably, we can speak of:

- the European information and cancellation rights from the distance selling and package travel directives. ${ }^{54}$

\footnotetext{
50 See TDA, ss 1-5 and 14; and Willett and Morgan-Taylor, above n. 6, at 7.8.3.1.

51 UCPD, Art. 3 (1)/CPUTR, Reg. 2 (1).

52 For a misleading practice under the CPUTR/UCPD, the information must be false or be likely to deceive the average consumer and it must causes or be likely to cause the average consumer to take a transactional decision he would not have taken otherwise (UCPD, Art. 6 (1)/CPUTR, Reg. 5 (2) (a)-(b)); and 'transactional decision' includes a decision as to whether to exercise a contractual right (UCPD, Art. 2 (k)/CPUTR, Reg. 2 (1)).

53 See Twigg-Flesner (2008), above n. 24.

54 Above n. 15; implemented in the UK by the Consumer Protection (Distance Selling) Regs. 2000, SI 2000/2334; and Package Travel, Package Holidays and Package Tours Regs. 1992, SI 1992/3288. See now the expansion of European information obligations contained in the Consumer Rights Directive (2011/83/ $\mathrm{EU})$.
} 
- the European concept of fairness that applies to most standard terms $;{ }^{55}$

- the European conformity standard applicable to sale and supply of consumer goods and the European 'cure' remedies of repair and replacement from the Consumer Sales Directive. ${ }^{56}$

The UCPD's general clauses on practices do not apply in private law as such. As is well known, UCPD Article 3 (2) provides that the directive is "without prejudice to contract law and, in particular, to the rules on the validity, formation or effect of a contract'. In other words, there is no direct obligation on member states to provide consumers with private law remedies where contracts are negotiated, concluded, performed or enforced in ways that are unfair within the meaning of the general clauses on misleading actions or omissions, aggressive practices, or professional diligence.

Of course, there are pre-existing private law remedies in the UK for practices such as misrepresentation (rescission and damages), and duress and undue influence (rescission). (It should be emphasised here that action to rescind the contract must be taken by the party - here the consumer - affected by the practice, i.e. the contract is voidable, not void.) These concepts obviously cover a fair amount of the same ground as is covered by the misleading and aggressive practice concepts from the UCPD. At the same time, they are not necessarily always as protective as the UCPD concepts. ${ }^{57}$ Nevertheless, when the Directive was first implemented, the UK chose not to extend the availability of private law remedies to cover cases of unfairness as defined by the UCPD general clauses. ${ }^{58}$

However, it was always likely that private law would be Europeanised in less direct ways by the UCPD concepts of fairness. Such 'spontaneous' or 'spillover' Europeanisation might occur in the following ways ${ }^{59}$ First of all, even if compliance with the standards set by the general clauses cannot be enforced through private law action as such, these standards inevitably affect contracting practice. As we have noted above, the UCPD general clauses apply 'before, during or after' any 'commercial transaction' ${ }^{60}$ So the European standards of fairness set by these general clauses determine how traders must behave towards consumers while seeking to persuade them to enter contracts, negotiating contracts and during the performance and enforcement of contracts.

Second, there is always the possibility that the courts may develop pre-existing domestic concepts (e.g. misrepresentation, duress, undue influence) incrementally in ways that reflect the UCPD general clauses.

Finally, the Law Commissions have been working on proposals for the introduction of some statutory private law remedies for at least certain violations of the UCPD general clauses. ${ }^{61}$ In brief, the idea is that there would be rescission and price reduction remedies on a 'strict liability' basis, while traders would be able to avoid damages liability by establishing that they had exercised 'due diligence' in seeking to avoid carrying out the practice in question. The remedies would not be available for misleading omissions or violation of professional diligence. This does mark a serious restriction on the degree of Europeanisation, given that these are two key 'European' concepts that have not played a significant role in UK private law.

\footnotetext{
55 Above n. 17; implemented in the UK by Unfair Terms in Consumer Contracts Regs. 1999,SI 1999/2083; and see C. Willett, Fairness in Consumer Contracts: The Case of Unfair Terms (2007).

56 Above n. 16, implemented by Sale and Supply of Goods to Consumers Regs. 2002, SI 2002/3045.

57 See generally Willett, above n. 1; and Willett, above n. 21 .

58 The idea was that the Law Commissions should investigate more fully the way in which the UCPD concepts could interact with the traditional UK concepts. See now Law Commission, A Private Right of Redress for Commercial Practices (2008); Consumer Redress for Misleading and Aggressive Practices, LCCP 199, April 2011; and Law Commissions, Consumer Redress for Misleading and Aggressive Practices, Law Com 332, Scot Law Com 226, 2012. See further below on this work.

59 Generally on such forms of harmonisation, see W. Van Gerven, ERPL (2001) 492 and M.B.M. Loos, ERPL (2007) 515. For an excellent early analysis of the issue see S. Whittaker, 'The Relationship of the Unfair Commercial Practices Directive to European and National Contract Laws', in S. Weatherill and U. Bernitz, The Regulation of Unfair Commercial Practices (2007). Also, see Willett, above n. 1; and Willett, above n. 21.

${ }_{60}$ UCPD, Art. 3 (1)/CPUTR, Reg. 2 (1).

${ }^{61}$ See above n. 58.
} 
Nevertheless, the new remedies would be available for misleading actions and aggressive practices. The misleading action concept is perhaps not sufficiently different from domestic misrepresentation for us to say that the introduction of private law remedies in relation to it involves a significant Europeanisation. ${ }^{62}$ However, the aggressive practice concept has the potential to be understood in a significantly different and more protective way than the domestic duress and undue influence concepts. ${ }^{63}$ So, introducing private law remedies for breach of the aggressive practice concept may significantly Europeanise this branch of consumer private law. Further, this is a potentially important area in practice, as it is where consumers must look for private law remedies against high-pressure selling and debt collection by traders.

\section{Full Harmonisation, Minimum Harmonisation and Limits to Europeanisation: Financial Services}

\subsection{Full Harmonisation}

We have already seen that the CPUTR repealed key generally applicable rules on trade descriptions and misleading pricing. It also repealed a very large number of rules dealing with more specific types of practice. ${ }^{64}$ One reason for all of these repeals was to foster simplicity, i.e. to avoid having complicated overlap and duplication as between the main piece of legislation (the CPUTR) and large numbers of pre-existing rules. However, another key reason for repealing as much as possible of the old law was the full harmonisation clause in Article 4, which provides that:

Member States shall neither restrict the freedom to provide services nor restrict the free movement of goods for reasons falling within the field approximated by this Directive.

The final section (below) will suggest that the UCPD concepts often offer the potential to provide greater protection than was provided by pre-existing law. Nevertheless, the more pre-existing law remaining on the statute book, the greater the risk that some of it might, in some or other way, exceed the level of protection offered by the UCPD concepts. So in order to avoid this risk of offending against the full harmonisation principle in Article 4, vast swathes of pre-existing law were repealed; this further reinforcing the Europeanisation process that has been the key narrative of this article so far.

\subsection{Minimum Harmonisation and the Limits of Europeanisation: the case of Financial Services}

Notwithstanding the significant Europeanising effect of the UCPD as explained above, 'home grown' UK rules may continue to play the main regulatory role in the areas of financial services and immovable property, which are exempted by Article 3 (9) from the full harmonisation principle that applies generally under the UCPD. In these sectors, there is, in effect, the minimum harmonisation that has generally applied in the past to consumer protection directives.

We will focus here on financial services as it is such an important element of the consumer economy. The 'home grown' regime here operates within a well-established institutional structure and (as is permitted by Article 3(9)) may well set higher standards of protection than those in the UCPD. ${ }^{65}$

\footnotetext{
Although the price reduction remedy would be a useful one that does not exist currently for common law misrepresentation.

63 See Willett, above n. 1; Willett, above n. 21; and see further below at notes 82-87 and related text.

64 CPUTR, Schedule 4.

65 For similar conclusions in relation to immovable property, see Civic Consulting, Study on the Application of Directive 2005/29/EC on Unfair Commercial Practices in the EU (2012).
} 
We will concentrate on the regime regulating secured credit. ${ }^{66}$ Currently, secured credit (covering the first legal charge over a borrower's home) and other financial services are regulated by the FSA under the Financial Services and Markets Act (FSMA) $2000{ }^{67}$ This is done under the rules in the Financial Services Authority (FSA) Handbook (specific and detailed rules dealing with specific practices) ${ }^{68}$ the general principles for business ${ }^{69}$ the Treating Customers Fairly (TCF) Outcomes ${ }^{70}$ and the CPUTR (the regime implementing the UCPD). ${ }^{71}$

Certainly, it is difficult to make definitive comparisons between the very opentextured general principles for business, the TCF Outcomes and the similarly opentextured (but differently worded) definitions of 'unfair' practices from the UCPD. Comparison is further complicated by the huge volume of more specific rules (contained in the FSA Handbook), which support and complement the more general FSA principles of fairness. ${ }^{72}$ The problem here is to say whether (as well as reflecting the broad FSA principles) these Handbook rules can be said to represent a natural 'unpacking' of the broader UCPD standards of fairness or whether they go beyond this and provide greater protection.

Nevertheless, we would suggest that the FSA principles may often set higher standards than the UCPD. First of all, let us consider the rules on misleading actions. Violation of the UCPD 'misleading action' provision must involve information as to one of the matters on the list contained in Article 6(1)(a)-(g). This could be considered to be an exhaustive list, and although it is very broad in scope, it does not necessarily cover every potential type of information. However, a practice might certainly be considered to be misleading, and therefore unfair, under the FSA regime despite not involving information on the list in Article 6 (1). FSA general principle 7 refers to the obligation to 'communicate information to [consumers] in a way which is clear, fair and not misleading', and this applies whatever the subject matter of the information.

Also, under the UCPD, it is not sufficient to establish that the practice would mislead the average consumer. It must, in addition, be shown that the impact of the practice is or is likely to be such that the average consumer would take a 'transactional decision' different from that which they would take otherwise. ${ }^{73}$ This requirement can make a difference to whether a practice is unfair or not. For instance, a price or other charge that is understated by a few pence arguably still misleads the average consumer, but may be

$\overline{66}$ For similar conclusions in relation to unsecured credit, see Civic Consulting, above n. 65.

67 The FSA is responsible for both protecting consumers and maintaining confidence in the financial markets (FMSA, ss. 2, 3 and 5); and see the rule-making powers in FMSA, s. 138, as amended by Financial Services Act 2010, ss. 3 (4) and 26 (1) (c). No firms are allowed to operate (provide regulated financial services) in the first place until the FSA has given them permission to do so. NB that plans are currently being discussed for a transfer of the consumer protection function of the FSA next year to a new 'Financial Conduct Authority': see Financial Services Bill 2010-12 to 2012-13 available at http://services.parliament. uk/bills/2010-12/financialservices.html and M. Wheatley, 'Journey to the FCA', FSA/PN/092/2012, available at $<$ http://www.fsa.gov.uk/library/communication/pr/2012/092.shtml $>$.

68 Available at $<$ www.fsa.gov.uk/Pages/handbook/index.shtml $>$.

69 Full Handbook, Principle 2.1, available at $<$ https://fsahandbook.info/FSA/html/handbook/PRIN/2/1>. 70 FSA, Treating Customers Fairly, available at <www.fsa.gov.uk/Pages/Doing/Regulated/tcf/index. shtml>; and see J. Black, M. Hopper, \& C. Band, Making a Success of Principles Based Regulation (2007), Law and Financial Markets Review 191; T. Williams, 'Open the Box: An Exploration of the Financial Service Authority's Model of Fairness in Consumer Financial Transactions', in J. Devenney, L. Fox O'Mahony, and M. Kenny (eds.), Unconscionability in European Private Financial Transactions (2010) 227; and P. Cartwright, 'Conceptualising and Understanding Fairness: Lessons from and for Financial Services', in J. Devenney, L. Fox O’Mahony, \& M. Kenny (eds.), Unconscionability in European Private Financial Transactions (2010) 205.

${ }_{71}$ On the approach of the FSA to the UCPD/CPUTR generally see <www.fsa.gov.uk/Pages/About/What/ International/ucp/index.shtml $>$.

Note also that the OFT is the main enforcer under the CPUTR, but there is an agreement between the OFT and the FSA on division of responsibilities for financial services matters-see Concordat between the OFT and FSA, November 2009, at <https://webmail.dmu.ac.uk/exchweb/bin/redir.asp?URL=http://www. fsa.gov.uk/pubs/other/concordat_fsa_oft_08.pdf>.

${ }_{72}$ The Handbook subdivides into separate 'sub' books containing hundreds of rules on such issues as mortgages and home finance, insurance, banking, client assets, building societies, collective investment, credit unions, and dispute resolution.

${ }_{73}$ UCPD, Art. 6 (1). 
unlikely to cause him or her to contract for a service or product that they would not have bought in any case. If not, the understated price or charge will not be misleading under the UCPD. However, it would arguably be misleading under the FSA regime, which contains no 'transactional decision' requirement.

Turning to 'misleading omissions', first of all, the UCPD test turns on whether the information is 'material' and is 'needed' by the 'average consumer'. The TCF Principles simply say that consumers should be provided with 'clear information and ... kept appropriately informed'. Secondly, as with misleading actions, there is only a misleading omission under the UCPD, where the omission is likely to cause the average consumer to take a 'transactional decision' different from that which they would take otherwise. ${ }^{74}$ As indicated above, there is no such requirement in the FSA general principles. Third, the FSA wrote to the payment protection insurance industry to remind them of typically unacceptable practices at the point of sale that had come to the FSA's attention. One of these was that:

The firm did not take reasonable steps to ensure the customer only bought a policy for which he was eligible to claim benefits. ${ }^{75}$

There is at least room for debate as to whether information as to eligibility would necessarily be 'needed' or 'material' under the UCPD test.

Now turning to aggressive practices, there are a number of requirements that are specific to the UCPD 'aggressive practices' clause that do not need to be established for there to be unfairness under the FSA regime. These requirements may mean that the FSA regime provides a higher level of protection than the UCPD regime. So under the UCPD, one route to establishing an aggressive practice is to show that there is 'coercion or harassment' leading to an actual or likely 'significant restriction' on the average consumer's 'freedom of choice or conduct'. ${ }^{76}$ Otherwise, it must be shown that there is 'undue influence', for which there must be 'exploitation' of a 'position of power' through 'pressure', which 'significantly' impairs (or is likely to so impair) the average consumer's 'freedom of choice or conduct', specifically, here, by 'significantly' limiting the ability of this average consumer to take an 'informed decision' ${ }^{77}$ None of these criteria are mentioned in discussing fairness/unfairness in general under the FSA regime. So it is plausible that practices (pressure selling, aggressive enforcement etc.) might fail to meet these particular UCPD criteria but still be sufficient to amount to unfairness under the more open-textured FSA regime.

Then, as with misleading practices, there is the requirement of 'transactional decision making', which applies to all UCPD concepts. In the case of any practice claimed to be aggressive under the UCPD provisions, it must be shown that the result of the coercion, harassment or undue influence would be (or be likely to be) that consumers would take a transactional decision different to the one they would have taken otherwise. ${ }^{78}$ As we have seen, the concepts of fairness under the FSA regime do not contain such a requirement. So there could be aggressive behaviour that is of a more one sided, unilateral nature, where the business simply imposes a detrimental outcome on a consumer or withdraws a service from a consumer. This has the potential to be viewed as unfair under the general FSA concepts of fairness, but it would be more difficult to show that it affects consumer transactional decision making as such (as required under the UCPD) ${ }^{79}$

What is clear from the above discussion is that regulation of secured credit operates within a well-established domestic institutional structure and may well set higher standards of protection than those in the UCPD. For these reasons, along with the

\footnotetext{
74 Art. 7 (1).

75 FSA, Consultation Paper 10/6, The assessment and redress of Payment Protection Insurance complaints Feedback on CP09/23 and further consultation, App. 3, Point 6.

76 Art. 8.

77 Arts 8 and $2(\mathrm{j})$.

78 UCPD Art. 5.

79 See discussion in Willett, above n. 1 on possible ways around this problem.
} 
minimum harmonisation allowed by Article 3(9), this home grown regime is likely to remain the dominant force in financial services regulation, ${ }^{80}$ with the European UCPD norms being unlikely to play a major role.

\section{Judicial Approaches to Europeanisation}

\subsection{The Potential to Increase Standards of Protection Relative to Pre- existing UK law}

In contrast to the position just described in relation to financial services, the UCPD generally has the potential to increase standards of protection relative to pre-existing UK law. This is something that has been demonstrated at length elsewhere; ${ }^{81}$ and there is no space here to provide a systematic comparison between the UCPD and pre-existing UK standards. However, it is worthwhile providing some key examples.

To begin with, there is the UCPD 'misleading omissions' concept. ${ }^{82}$ It is well known that there has never been such a general rule against omissions in UK domestic law, so there is clearly now potential for a higher level of protection. Next, one might cite the 'undue influence' limb of the aggressive practices general clause. ${ }^{83}$ This, as outlined above, covers exploitation of a 'position of power' through 'pressure', which 'significantly impairs' (or is likely to so impair) the average consumer's 'freedom of choice or conduct', specifically by significantly limiting the ability of this average consumer to take an 'informed decision' ${ }^{84}$ Pre-existing UK domestic criminal and preventive rules focused mainly on the specific problem of harassment of debtors. ${ }^{85}$ The UCPD undue influence concept seems to have the potential to cover much more than this. For example, greater trader knowledge/skill might be considered to create a 'power relationship' and the potential for 'pressure' at the sales stage. In this context, some high-pressure selling might well amount to undue influence, where, for instance, consumers are put on the spot to make quick decisions (the decision may, then, not be 'informed', as there was insufficient time to think it through). Post contractually, the power relationship and pressure might come, for instance, from vulnerability when struggling with commitments. This might enable traders to pressure consumers into new commitments, refinancing etc. Clearly, these examples go well beyond what is covered by rules on harassment of debtors. They also extend beyond the traditional scope of domestic private law undue influence. Inter alia, this requires a special relationship of trust and confidence (rather than just a 'relationship of power'), and has, in practice in modern times, been restricted to the 'bank guarantee' scenario. ${ }^{86}$

In summary, then, the point is that (outside the financial services sphere) the UCPD's European concepts of fairness contain the potential to increase levels of consumer protection in the UK. In this sense, the 'Europeanising' effect of the UCPD could be said to be all the more significant. Not only does the UCPD Europeanise the preventive, criminal and private law tools (as shown in the first part of this article), but it also Europeanises the substantive level of protection provided.

\footnotetext{
${ }_{80}$ The FSA regime appears to be very much the first 'port of call' for the FSA, the UCPD regime being viewed as a relatively residual 'back up'.

81 See Willett, above n. 1; and Willett, above n. 6.

82 UCPD, Art. 7/CPUTR, Regs. 6.

83 Generally, see Willett, above n. 1; Willett, above n. 6; and Cartwright, above n. 6.

84 And thereby causes him to take or be likely to take a transactional decision he would not take otherwise: UCPD, Arts. 8 and 2 (j)/CPUTR, Regs. 7(1) and (3)(b).

85 Administration of Justice Act 1970, s. 40.

86 RBOS v. Etridge (No. 2), [2002] 2 AC 773 for a summary of the cases and a re-statement of the rules.
} 


\subsection{Some Illustrative Cases $^{87}$}

So far, the evidence suggests that judges have taken a relatively protective approach to interpretation of the UCPD concepts.

For example, from a consumer protection perspective, one perennial risk with concepts of 'fairness' or 'good faith' is that they will be understood to require subjective dishonesty by the trader. Now we have noted above that, in the case of the 'professional diligence' concept, there is only criminal liability under the UK regime where there is indeed mens rea in the form of intention or recklessness by the trader ${ }^{88}$ There is no mention of trader intention or recklessness where preventive control measures (enforcement orders) are concerned. At the same time, professional diligence is defined for all purposes, by reference, inter alia, to 'honest market practice' ${ }^{89}$ Nevertheless, the High Court has resisted any temptation to read this in a non-protective way. It was made clear in Tiscali UK Ltd v. British Telecommunications Plc that there was an 'objective' test of dishonesty, in that it was not necessary to demonstrate that at the time of the offending statement, its maker knew it to be false or had no honest belief in its truth. ${ }^{90}$

Another encouraging decision from a consumer protection perspective is OFT v. Purely Creative. ${ }^{91}$ This case dealt with whether various 'scratchcard' promotions violated the general clauses on misleading actions and omissions. On the facts, it was held that some did and some did not. However, the key point for our purposes is that the High Court understood the 'average consumer' concept by reference to a relatively protective ethic, recognising that such a consumer will not necessarily read all information provided. ${ }^{92}$

This case is obviously significant in the context of the misleading action and omission concepts. It suggests that courts should focus on the main information provided (or not provided, where omissions are concerned) in deciding whether the average consumer is likely to be misled and caused to take a transactional decision that would not otherwise be taken. This core information (or lack of it) is what should determine whether there has been a misleading action or omission rather than information provided in supplementary form, small print etc.

Such an approach could also suggest a protective approach to the 'undue influence' limb of the aggressive practices concept. As indicated above, the undue influence concept turns on whether consumers have been prevented by 'pressure' from making an 'informed decision.' If this was understood in a non-protective way, the interpretation might be that if trader pressure is followed by a formal transparent explanation of risks, the average consumer is now able to take an 'informed decision', and there is, therefore,

\footnotetext{
87 Aside from the cases discussed here, for examples of cases decided under the CPUTR, see also McGuffick v. Royal Bank of Scotland Plc, [2009] EWHC 2386; Kingspan Group Plc v. Rockwool Ltd, [2011] EWHC 250 (Ch); and OFT v. Peter Hall (available at <www.oft.gov.uk/news-and-updates/press/2010/38-10>).

88 See note 32 and related text.

89 Art. 2 (h)/CPUTR, Reg. 2 (1).

90 [2008] EWHC 3129 (QB).

91 [2011] EWHC 106 (Ch). The defendants have appealed this decision to the Court of Appeal, whose decision has been stayed pending a reference to the ECJ to determine the scope of Para. 31 of Ann. 1 to the Directive (i.e. the list of practices that are always to be considered unfair, without the need to apply one of the general tests of unfairness). The questions referred explore whether Para. 31 prohibits traders from telling consumers that they have won a prize if any of the methods of claiming it involve any charge (even a de minimis one) being incurred by the consumer; what is actually meant by de minimis; and whether a 'false impression' of winning a prize depends, inter alia, on the relative value of the prize when compared with the cost of claiming it ([2011] EWCA Civ 920). See below n. 95-96 and related text on the ECJ decision. For a discussion see M. Morgan-Taylor, 'Preventing Distribution of Promotions to Consumers Involving Unfair Practices - OFT application for Order under Enterprise Act 2002: OFT v. Purely Creative Ltd et al', 16 Communications Law 115 (2011).

92 Id., para. 66. This 'average consumer' concept (who is deemed to be 'reasonably well informed and reasonably circumspect' is, of course, the core benchmark for assessing practices under the regime (UCPD, Arts. 5-9, Preamble, recital 18/CPUTR, Reg. 2 (2)). Of course, this standard can be varied to the average member of targeted or vulnerable groups of consumers (UCPD, Arts. 5(2)(b) and 5 (3)/CPUTR, Regs. 2 (4) and 2 (5)). There is no space here to discuss these alternative benchmarks. However, see discussion in Willett, above n. 6; and see, for example, the OFT work on mental capacity: OFT, Mental Capacity consultation (OFT 1293con), available at <www.oft.gov.uk/news-and-updates/press/2010/127-10>.
} 
no undue influence. However, if we follow the logic of the approach in the Purely Creative case, this would be an unlikely conclusion. Purely Creative, as we have seen, takes the line that consumers will not necessarily read all information provided. It seems to follow from this that standardised explanations of risks are even less likely to be read where the average consumer has been affected by pressure from the trader. In short, the Purely Creative decision suggests that, where there is significant trader pressure, this should raise a very strong presumption that the average consumer is likely to be prevented from making an 'informed decision' (a presumption that it should be very difficult to overturn by reference to evidence about standardised explanations as to the risks).

The most recent case was Ashbourne Management Services Limited. ${ }^{93}$ The plaintiff in this case was the OFT, while the defendant was a company that specialised in recruiting gym members for fitness clubs across the country. The case concerned, inter alia, threats to report consumers to credit reference agencies for non-payment of sums allegedly due under the agreements with the gyms. For our purposes the important point is that the High Court decided that such threats amounted to aggressive practices where the sums in question were legitimately in dispute and where the sums were no more than claims for unliquidated damages. This seems to approach the aggressive practices concept in a relatively protective manner. It takes account of the very significant detrimental impact on consumers of being reported to a credit reference agency and therefore having a poor credit record that will affect future attempts to borrow money. Importantly, also, it seems to recognise that traders should not simply be viewed as having a legitimate interest in taking any otherwise legal action to protect their interests. They should be expected to take seriously any genuine dispute as to the validity of their claim.

\section{Concluding Comments}

This article has demonstrated that the UK has implemented the UCPD via a mixture of preventive and criminal enforcement techniques, but that these techniques have been 'Europeanised' by the open-textured nature and significant breadth of application of the UCPD concepts. It has also shown that the UCPD may also lead to a more spontaneous (less direct) Europeanisation of UK private law, in particular by moving towards introducing remedies for certain violations of the UCPD concepts of fairness.

At the same time, we have demonstrated an important limit to the Europeanisation brought about by the UCPD. In the hugely important financial services sector, Article 3 (9) of the UCPD, inter alia, is likely to mean that the pre-existing domestic regime will not be significantly Europeanised by the UCPD concepts.

In the latter part of the article, we focused on the role of judges when it comes to the reception of the UCPD in the UK. It was argued that the UCPD's European concepts of fairness often have the potential to increase consumer protection in the UK, and that, so far, UK judges have been relatively protective in the way in which they have interpreted these UCPD concepts.

Of course, as we have noted many times throughout this article, the UCPD unfairness concepts are of a rather 'open-textured' nature. This means that, while they can (and have so far) been interpreted in relatively protective ways, they might also be interpreted in ways that are rather more grounded in values of trader self-interest and consumer self-reliance. For instance, for the purposes of the misleading action concept, it might be taken that consumers can be expected to read not only the 'headline' information, but also less prominent information that in some way qualifies or negates a misleading impression that has been given by the headline information. Further, to revisit the example of undue influence above, if this was understood in a non-protective way, it might be said that if trader pressure is followed by a formal transparent explanation of risks, the average consumer is now able to take an 'informed decision', and there is no undue influence.

93 Office of Fair Trading v. Ashbourne Management Services Limited, John Clayton-Wright and Dawne Clayton-Wright, [2011] EWHC 1237 (Ch). 
The point is that so far there have only been High Court decisions. We have yet to hear the views of the Court of Appeal or the Supreme Court ${ }^{94}$ on such matters. So we cannot be sure as yet as to what ethic of fairness will ultimately take hold in the UK. The Court of Appeal in the Purely Creative case made a reference to the ECJ. ${ }^{95}$ Of course, this reference goes to questions as to the interpretation of paragraph 31 of Annex 1 to the Directive and not to interpretation of the general tests of unfairness (i.e. the clauses on misleading and aggressive practices and on professional diligence). The guidance will therefore be of limited general assistance. Nevertheless, it may still tell us something as to the attitude of the ECJ to the level of protection intended. The ECJ decided that when para. 31 refers to a 'false impression' in relation to winning a prize (when in fact this is subject to some action or cost for the consumer), this, inter alia, includes cases where any one of the optional ways in which to claim the prize requires the consumer to incur any cost whatsoever. The Court explained that para. 31 aims to address the aggressive practice of exploiting the psychological effect of being told a prize has been won, this being likely to induce consumers to take the irrational choice of choosing the more expensive (but quicker) route (e.g. a premium rate call) to discover the nature of the prize. ${ }^{96}$ This suggests that the ECJ is sensitive to the potential for consumer freedom of choice to be readily compromised when 'put on the spot' by attractive offers that tend to induce speedy and economically detrimental decisions. We must now wait to see whether the UK (and other national courts) are inclined to make references under the aggressive practices (or the other) general clauses and whether the ECJ chooses to take to carry over this relatively protective approach from para. 31 to its interpretations of the general clauses.

\footnotetext{
94 See Willett, above n. 21, where one of the present authors argues that (i) the Supreme Court has chosen to unpack and apply the similarly open-textured general clause on unfair contract terms (and associated provisions) (from Directive 93/13/EEC) by reference to an ethic of trader self-interest and consumer selfreliance, rather than by reference to an ethic of protection; and (ii) that this is in contrast to the more protective approaches taken by the OFT and the Court of Appeal. This may be one reason why the Court of Appeal chose to make a reference to the ECJ in the Purely Creative case (above, n. 91). But see n. 96 below on the limits of this reference.

95 See above, n. 91.

96 C-428/11.
} 